\title{
The Memory Politics of Becoming European: The East European Subalterns and the Collective Memory of Europe
}

\author{
MARIA MÄLKSOO \\ International Centre for Defence Studies, Tallinn, and \\ University of Tartu, Estonia
}

\begin{abstract}
The situation in collective memory studies that share a nexus with the discipline of International Relations (IR) is currently reflective of the traditionally West-centric writing of European history. This order of things has become increasingly challenged after the eastern enlargement of the European Union (EU). This article examines Poland's and the Baltics' recent attempts to enlarge the mnemonic vision of 'the united Europe' by placing their 'subaltern pasts' in contest with the conventionally Western European-bent understanding of the consequences of World War II in Europe. I argue that their endeavours to wrench the 'European mnemonical map' apart in order to become more congruent with the different historical experiences within the enlarged EU encapsulate the curious trademark of Polish and Baltic post-Cold War politics of becoming European: their combination of simultaneously seeking recognition from and resisting the hegemonic 'core European' narrative of what 'Europe' is all about.
\end{abstract}

KEY Words $\bullet$ Baltic states $\bullet$ legacy of communism $\bullet$ memory politics - Poland $\bullet$ World War II

The situation in collective memory studies that share a nexus with IR is currently reflective of the traditionally West-centric writing of European history. So far, the main focus of students of the relationship between collective memory and international politics has largely been on German or the other West European collective remembrance practices, and their implications for international relations. While the recollection of the Holocaust has become increasingly institutionalized and internationalized, the crimes of

European Journal of International Relations (C) The Author(s) 2009. Reprints and permissions: http://www.sagepub.co.uk/journalsPermissions.nav, Vol. 15(4): 653-680

[DOI: $10.1177 / 1354066109345049]$ 
the communist regimes and their traumatic repercussions for contemporary European politics have hardly received comparable academic and political attention. Eastern European memories of World War II are still les lieux d'oubli rather than parts of les lieux de mémoire of the officially endorsed collective European remembrance of the war (cf. Nora, 1995; Wood, 1999). The realities of the war in Eastern Europe have generally been concealed in the Western public consciousness and formed the byways rather than institutionalized parts of the 'European account' of World War II. Moreover, their analysis as on a par with Western European experiences with the atrocities of World War II remains a topic of debate even among the critical memory scholars.

This order of things has been progressively challenged after the eastern enlargement of the EU, however. The 'new Europeans' are contesting the memorial status of their experiences of World War II in the EU-endorsed remembrance of this war as ultimately a 'good war' where the Allied Coalition was supposedly acting on the common ground of anti-Nazism (cf. Davies, 2006: 246). This seeming mnemonical consensus has been gradually unravelling from multiple angles lately, as Zehfuss's (2007) account of the controversial memory politics of World War II in Germany and Davies's (2007) compelling re-examination of the conventional narrative of World War II illuminate. We could distinguish at least four major mnemonic communities in the European memory landscape in relation to World War II: Atlantic-Western European, German, East-Central European and Russian. Their remembrances of the war focus respectively on D-Day of 1944 and the Allied Victory in Europe on 8 May 1945; manifold traumas resulting from the experience of bombing raids and total defeat; the trials of undergoing Nazi and Soviet occupations in succession; and the comfort drawn from the costly victory in 'The Great Patriotic War' (Jarausch and Lindenberger, 2007: 4).

The Baltic states and Poland have emerged in the vanguard of the socalled 'new European' commemorative politics, demanding the inclusion of their wartime experiences in the pan-European remembrance of this war. Even a cursory look at the central themes in the Baltic and Polish postEU accession foreign and security political debates will reveal their quite remarkable preoccupation with the implications and ramifications of World War II in Eastern Europe. The Latvian president's applauding of the NATO summit in Riga in November 2006 as a sign of the ultimate end of World War II in the region; the Polish prime minister's pointing to Poland's suffering in the war as a moral argument for giving it the voting weight of much more populous Germany in the EU Council of Ministers in June 2007; the Estonian government's reordering of the World War II-related sites of memory in the country - all this speaks of the increasing invocation of 
the traditionally subaltern collective remembrance practices in these East European states' foreign policy-making of the day.

Polish and Baltic political elites' endeavours to wrench the 'European mnemonical map' apart in order to become more congruent with the different historical experiences within the enlarged EU, as well as to gain EU support for influencing Russia to acknowledge its responsibility for the crimes of the communist regimes in Eastern Europe and the Soviet occupation in the Baltic states, demonstrate the curious trademark of their politics of becoming European: a combination of simultaneously seeking recognition from and exercising resistance to the hegemonic 'core European' narrative of what 'Europe' is all about.

This article critically engages with the significance of memory politics in Polish and Baltic post-Cold War processes of becoming European as a pivotal resistance move to their traditionally liminal status in Europe. Polish and Baltic politics of 'becoming European' is conceived here as a quest to be part of the 'true Europe' as opposed to 'Europe but not quite Europe' a position they have been designated by Western Europeans since the Enlightenment (cf. Wolff, 1994; Connolly, 1999). Their 'becoming European' has essentially been a struggle to gain recognition of Poland's and the Baltics' 'full Europeanness' from the authoritative social carriers of this desired identity and the concurrent rebellion against the occurrences of perceived misrecognition of Eastern Europe as 'lesser European' compared to its Western counterpart. If we regard coming to terms with the past as reinforcement of one's self-consciousness (cf. Adorno, 1986: 128), Polish and Baltic calls for equal remembrance of their pasts emerge as an essential part of their individuation process as European, of their becoming a European subject.

The first two sections of the article outline the different phases of remembering and the consequently diverging narratives of World War II in the East and West of Europe. I then turn to the case in focus used to explore the memory-political dimension of Polish and Baltic post-EU accession politics of becoming European. This part of the study draws on a discourse analysis of foreign policy establishments' speeches and interventions on the implications of World War II and the crimes of the communist regimes in Poland and the Baltic states against the backdrop of the commemoration of the 60th anniversary of the end of World War II in Moscow in 2005. ${ }^{1}$ I argue that Poland's and the Baltics' insistence on 'setting the past record straight' by seeking an all-European condemnation of the crimes of Soviet communism in Eastern Europe as equal to those of Nazism signals their fundamental insecurity about their immediate past's compatibility with the Western European states' own, and thus their persistent sense of 'liminal Europeanness' in the enlarged EU. Their excessive pondering on the memory 
of the Western betrayal of Eastern Europe in World War II thus emerges as a key indicator of their European identity-related insecurities, revealing uncertainty about 'whether the past really is past, over and concluded, or whether it continues, albeit in different forms' (see Said, 1994: 3).

At the same time, however, the Baltics' and Poland's increasing emphasis on the 'right to memory' also implies their escape from the restrictions inherent in their 'memory work' during the EU and NATO accession processes. In the course of this ritually liminal phase of becoming European, certain elements of their past had to be consciously put on hold without an opportunity to reflect on them in any deep manner before the context had become more 'enabling' for such reflection and, consequently, for a more autonomous construction of their selves. The Baltic and Polish foreign policy-making elites' reaffirmation of their countries' special situation in the context of World War II and resistance to the mnemopolitical authority of the West in delineating the contents of post-war 'European history' thus also signify Eastern Europe's post-EU accession ideological decolonization. As such, Poland and the Baltics challenge Western Europe's intention to act as the model for the whole of Europe, by which Western Europe sets the rules of remembrance to the 'new Europeans' even after their formal acceptance into the EU. The post-EU accession memory-political endeavours of Poland and the Baltic states could thus be conceived of as an attempt to insert a moment of radical heterogeneity into the historically largely Western European construction of 'Europe' - its history, memory and identity and to consequently pluralize the ways of being European.

A separate question is to what extent the 'old Europeans' would actually be willing to listen to the counter-narratives of the Easterners, or, moreover, whether the multitude of immediate historical perspectives in the 'new' and 'old' Europe could actually be reconciled into a more coherent and consensual new narrative without the silencing, subjugation or blunt forgetting of some stories for the sake of imposing and endorsing the dominance of others. ${ }^{2}$ After all, remembering and forgetting are by definition contentious issues. The memorial militancy of the 'new Europeans' has not always struck a resonant chord among their Western counterparts who have attempted to form a common European identity by 'drawing a line' under World War II. Yet again, the Baltic and Polish memory politics have brought up the controversial and intensely debated comparison between Nazi and Stalinist regimes and their respective crimes, thus contesting the uniqueness of Nazi crimes and questioning the singularity of the Holocaust as the crime against humanity of the 20th century. The upsurge of World War II-related memories in the East has thus often been regarded as obstructing the progress of the European project (cf. Bell, 2006). Against that backdrop, this article 
concludes with a critical discussion of the perspectives for the emergence of a more coherent and common 'memoryscape' for the enlarged EU.

It is striking that the attempts of the 'new Europeans' to introduce their 'counter-histories' to 'old Europe' in fact reflect the very 'core European' quest for security through integration in order to avoid fragmentation. Indeed, their calls for a broader European historical consciousness as a precondition for solidarity within the enlarged European polity implicitly regard the integration of distinct European experiences and memories as a panacea against future conflict (Kelam, 2008; Roszkowski et al., 2008). Moreover, the underlying assumption of the achievability of a common European mnemonical vision is in itself reflexive of the typically Western search for totality and universality through the creation of common structures (cf. McLennan, 2003: 75). The curiosity of the Baltic and Polish memory politics of becoming European therefore lies in their attempts to articulate their distinctive historical experiences from the perspective of the signifying position of the 'European subalterns' while resisting the totalization of the 'European majority memory of World War II', and yet assuming the real possibility of a unified and coherent common European remembrance of the war in the first place.

\section{Reclaiming the 'Right to Memory'}

Orientation to the past, rather than to the future, has often been regarded as part of some putative 'East European syndrome'. Yet, this typically Orientalist approach obscures the fact that memory, as well as forgetting, is a constitutive feature of any culture or social imaginary (cf. Zehfuss, 2006). Furthermore, the claims of a 'special historicism' of East European peoples, their heightened propensity to understand the present through the past and thus to see history as a weight restraining and enabling the choices that can be made in the present, deny the extent to which the 'memory boom' has also been a firm accompaniment in Western European societies in the late 20th and early 21 st centuries. This is nevertheless not to defy the 'historical nature' of postcolonial peoples as the flourishing 'minority memories' provide an important resource and means for regaining the past as part of a collectivity's identity-formation after decolonization. Yet, the idea of 'native East European historicism' has also been self-serving for the West, enabling it to disregard its own engagement in shaping the region's immediate past history. The permanence of the past in the former communist societies has not been an indication of another special 'East European pathology', but is merely consistent with the pattern of identity-formation in modern nationstates (Wydra, 2007: 238-9). 
The intensity of the presence of the past of 60 years in the current self-reflections of Estonia, Latvia, Lithuania and Poland reverberates an archetypical outburst of suppressed memories, a delayed affirmation of the 'right to memory' and the consequent efforts to release them from the burden of the officially mandated Soviet interpretations of World War II (see Judt, 2005: 821; Müller, 2002: 9). It further demonstrates critical attempts to break with the past by drawing lessons from it; indeed, to secure identity by reappropriating and reaffirming one's collective memory (see Norton, 1993: 460). While Western European nations had the privilege of starting anew immediately after World War II by drawing a clear line under the horrors of the past with what Winston Churchill (1946) called a 'blessed act of oblivion', Eastern Europe had to wait for its chance to begin peeling back the layers of ideological reinterpretations of its past(s) decades later. This is not to say, however, that the post-war 'new start' in Western European countries, such as in Germany and France, for instance, was in any way immediate and unproblematic. The 'blessed act of oblivion' in postwar Western European states that was thought necessary for their national recuperation also fostered a myriad of mismemories, self-delusions and myths about their respective roles in the war, as we know from the work of Tony Judt (1992, 1994), among others (cf. Deák et al., 2000). Furthermore, in the Germans' case, it was impermissible to legitimately remember their individual sufferings in World War II (such as the Allied bombings of German cities, the flight and expulsion of Germans from Eastern Europe and the painful 'liberation' of Germany in 1945) until recently, as the immensity of the internationally induced collective guilt overwhelmed and disabled all other public recollections of the war (cf. Zehfuss, 2007).

Nevertheless, there has been a fundamental temporal mismatch between phases of 'freezing' and 'unfreezing' of war memories in Western and Eastern Europe. Eastern Europeans' experiences of the war were 'frozen' for open historical debate and critical discussion for more than 40 years over the Cold War because of the Soviet regime's use of 'organized forgetting' and 'communicative silencing' as a political technique of control over the subjugated populations in the Eastern bloc (Wydra, 2007: 228). Although there was indeed an analogous 'glacis' of certain parts of the World War II-related past(s) in Western European countries in the immediate post-war years as succinctly captured by Henry Rousso (1991) in his analysis of France's 'Vichy syndrome' of denying, misremembering and abusing the memory of the wartime regime - this 'freezing' was nevertheless largely self-imposed. Indeed, it was a conscious choice of forgetting certain traumatic parts of one's past in order to provide a safe interregnum in which the building of a new identity could begin (Wydra, 2007: 226). 
The first phase of the breakout from the Soviet-enforced official mnemonical stasis of Eastern Europe began only in the immediate aftermath of the Cold War. The initial stage of the public defrosting of the postsocialist countries' memories meant engaging with former taboo subjects and revealing the falsifications and distortions of the past imposed upon them by the 'mnemonical hibernation' of the communist period (cf. Kwaśniewski, 2002). Such forced mnemonical cover-up had certainly applied to official forms of collective remembrance during the Soviet period, not least due to Eastern European societies being deprived of channels for their memories' political articulation and resources for collective protest and resistance. Forms of communicative and cultural memory, which remained largely beyond the control of centralized power, were nevertheless maintained even under the Soviet regime, as could be observed in instances like the revolutions in Hungary in 1956, Czechoslovakia in 1968 and Poland in 1980 (cf. Assmann, 1992). Moreover, opponents of communist regimes learned to exploit the outward manifestations of conformity for their own ends, thus allowing the curious practice of mnemonical 'double discourse' to flourish (cf. Lebow, 2003: 327; Miłosz, 1953).

If memory is by definition an 'arena of conflict' between forgetting as an action directed against the past, and the return of the forgotten, ${ }^{3}$ this truism was vividly played out in Eastern Europe after the break-up of the Soviet Union. Having been forced into a prolonged phase of mnemopolitical liminality over the communist period, Poland and the Baltic states had a chance to publicly evaluate their experiences of World War II only after the collapse of their respective communist regimes (Judt, 1992: 95; Szakolczai, 2000: 223; Wydra, 2007: 227-30). Eastern Europeans' public reassertion of their right to give voice to their own pasts in the post-Cold War phase also served to provide inspiration and consolation to people suddenly confronted with radical social and political change, a general sense of uprootedness, confusion, uncertainty and 'the stigma of being poor, backward cousins in the European family' (Mostov, 1998: 376).

Poland's and the Baltics' more recent, post-EU accession attempts to bring their pasts to the fore in the debates over European identity and security reflect their growing vocal claim for an 'equal subjectivity' in the European mnemopolitical field as well as demonstrating their increasing sense of confidence about the density of their ties to the Euro-Atlantic security community. This, in turn, enables them to remind their Western European counterparts openly about the need to remember European history in all its complexity as well as to discover the 'other in oneself'. What we witness now is hence a different kind of unfreezing of memory: the Eastern Europeans' casting off the restraints that the West had applied on their 'memory work' during the enlargement process of the EU and NATO. 
Whereas during this explicitly liminal phase in their 'becoming European' the candidate countries had to keep a low profile in reflecting on the historical sources of their mutually antagonistic relations with Russia, they are now all the more forcefully pushing for their 'remembrance right' to their own narrative of the events and aftermath of World War II. Reminding the West of its accountability for the Eastern European post-war security predicament has added a further critical European dimension to the most recent round of Polish and Baltic memory politics.

\section{'Our History is Your History Too': Hegemonic and Counter-begemonic European Narratives of World War II}

Revealing the 'historical truth' about the implications of World War II in Eastern Europe, by drawing attention to and seeking a pan-European acknowledgement of East European sufferings in the war, has become one of the key missions of Polish and Baltic post-EU accession foreign policy. Aiming to shake the Western European versions of the immediate European past, Polish and Baltic foreign policy-makers have called for the 'Europeanization' of 'European' memories: the inclusion of their distinct historical experience of World War II into the common historical consciousness of Europe.

While the experiences of East and West Europe in World War II were different, a common frame for their interpretation should not be an impossibility, or so their argument goes. The issue here is really not the 'absolute' or 'relative weight' of pain inflicted by the Nazi and Soviet regimes, but how the consequences of the pain - in terms of justice rendered but also justice attempted - are perceived in different parts of Europe (cf. Irwin-Zarecka, 1994: 78). The wounds of collective memory are arguably difficult to heal if they go publicly unnoticed. The Baltic states and Poland are asking Western Europe to broaden its set patterns of remembering Europe's immediate past by trying to step into the shoes of Eastern European countries. In order to reach their aim, they are determined to make their voice heard, to make their past acquire a firm presence in the pan-European historical consciousness and interpretation of its immediate past history (e.g. Vịke-Freiberga, 2004). Since 'every Pole and every Estonian' is part of European history, as the late president of Estonia argued, it purportedly gives an obligation to take into account Eastern European tragic experiences, 'our tens of Katyns of which most are still nameless and unknown till this day, to the consciousness of European, American and Russian democrats' (see Meri, 1993; cf. Meri, 1999b; Kalniete, 2003).

There has indeed been a noticeable imbalance in both the remembering and the study of immediate past in the East and West of Europe. While 
the atrocities of the Nazis have been analysed with remarkable rigour and depth, reaching even the levels of meta-criticism of Holocaust memory and representations (but cf. Lukas, 1997), the crimes of the communist regimes in the former Soviet bloc have not received similar academic and political attention in Europe. ${ }^{4}$ The investigators of the communist crimes have been 'hopelessly at a disadvantage' when compared to the investigators of the Nazi crimes, not merely as regards access to archives and resources, but also in terms of the moral and financial support of political and academic circles (cf. Meri, 1999a). ${ }^{5}$ Reflecting the different experiences of the West and East of Europe in World War II, this imbalance has largely been due to the fact that the legacy of Nazism has simply been more immanent and the reflection on it thus more urgent than that of communism to the traditional writers of 'European history' - the Western European states. Moreover, West Europeans' heightened alertness towards Nazism's monstrosities has been all the more amplified for it having arisen in the heart of 'civilized Europe', while communism could easily be shelved under the category of 'normal aberrations' in the 'Russian borderland of Europe' (Malia, 1999: xii).

Yet, the asymmetry in the remembering and research on the respective regimes' criminal records could also be attributable to the simple fact that there has never been a Soviet Nuremberg process of a sort which, after all, made technically possible the documentation of the crimes of Nazism in the first place. Since a similar lustration vis-a-vis communism's legacy in Europe has never occurred, ${ }^{6}$ the 20th-century history of Europe has arguably largely bypassed the Eastern European component, thus leading to a 'one-legged, one-sided, one-eyed' account of Europe's immediate past (Davies, 2006: $41)$.

The late Estonian president Lennart Meri remarked with some irony in the early 1990s that everybody was talking about the death of communism, yet no one had actually seen its body. The Polish and Baltic endeavours to seek international condemnation of the crimes of the communist regimes in Central and Eastern Europe could be regarded as attempts to reify the very demise of communism, or, indeed, to disinter its 'body'. ${ }^{7}$ The impartial reassessment of Europe's immediate history is thus presented as an issue of European security, for allegedly 'the re-evaluation of the dark spots of history builds confidence and promotes cooperation among states' (Pabriks, 2005).

Yet again, reifying the end of communism has been more problematic than that of Nazism, not least for the lack of a clear historical rupture with the former unlike the one that occurred with 'burying' the latter at the end of World War II. While the circumstances of the end of Nazism made it possible to actually isolate its 'body' by blaming its 'carriers' and the perpetrators of the regime's crimes for everything evil that had occurred in World War II 
in Western Europe, the fortune of the largely peaceful end of communism in 1989-91 has, if somewhat paradoxically, also been part of the problem with doing away with communism's problematic legacy in Eastern European states. The Polish and Baltic foreign policy-making elites' vigorous attempts to externalize their experiences of communism have also been remarkably uncritical and self-delusional at times, essentially camouflaging the extent to which the communist system and practices were actually internalized by the very people who lived for decades under this regime.

Nevertheless, against the backdrop of the search for the 'body of communism', the Polish and Baltic post-EU accession politics of memory emerges as a self-appointed mission to remind Europe about the complexities of its own past (e.g. Ilves, 2003). After all, as the Latvian president Vaira VikeFreiberga emphasizes, while the end of World War II meant liberation for the West, it meant 'slavery, occupation, subjugation and Stalinist terror' for the East $(2005 \mathrm{a}, 2005 \mathrm{~b})$. The criticism of the Allies' compliance with the demands of the Stalinist Soviet Union at Yalta and the consequent Western moral co-responsibility for the closing off of Eastern Europe behind the Iron Curtain during the Cold War thus runs as a red thread through the mnemopolitical discourse of Poland and the Baltic states. Although proudly emphasizing that the Western bringing of Eastern Europe into its fold should not happen 'just for the sake of historical justice or because of their assumed feelings of guilt', these two principles were nevertheless the main sword in the hands of Eastern Europeans in their post-Cold War endeavours to join the Euro-Atlantic structures. At the end of the day, the dual enlargement was framed entirely as the undoing of historic injustice towards Eastern European states; indeed, as a decomposition of the 'Yalta order', both by the 'demand'- and 'supply'-side of the process.

Yet, while making up for the old Yalta 'betrayal' was a psychologically purifying fact, much remains to be purged from the understandings of the immediate past in the now common European house. Emphasizing the duty of the European collective memory to do justice to the victims of communism and Nazism together, Poland and the Baltic Three insist that forgetting the meaning of the communist legacy in Eastern Europe would amount to a loss of Europe's moral compass. Europe is argued to have an obligation to remember the events of 60 years ago as European identity cannot supposedly stand apart from the responsibility for the past of the whole of Europe (e.g. Kristovskis, 2008). Polish and Baltic Members of the European Parliament (MEPs) have been particularly vigorous in criticizing the imbalance of the EU's historical approach that grants the victims of communism a 'secondclass status', calling for a common European effort to urge Russia to assess its own history and to apologize for the crimes of Soviet totalitarianism (e.g. Kelam, 2008). ${ }^{8}$ 
Combining discourses of redemption, suffering and unjust treatment, Polish and Baltic memory politics occasionally falls prey to so-called 'comparative martyrology' on the question of who has suffered the most (cf. Donskis, 1999: 478). As Eastern Europe arguably suffered in World War II for the sake of Western Europe's relative security and well-being, recognition and legitimation from Western Europe is sought for its very special moral worth. For the old members of the EU, the Polish and the Baltic representatives' constant appellations about Eastern Europe's historical suffering are awkward and occasionally irritating as their self-attributed martyrdom reminds the West of its co-responsibility for the complexity of the region's immediate past, and thus about 'the other in themselves' as well. Since victimhood gives the right to complain, to protest and make demands, Western Europe is placed in the uncomfortable position of owing a debt to Eastern Europe (cf. Todorov, 2003: 142-3).

Yet, remembrance of one's own woes tends to generally overrun the ability to perceive the suffering of others as if empathizing with the suffering of the others would reduce one's own relative suffering (cf. Courtois, 1999: 21). All collective recollections of World War II are accordingly inevitably partial, as the absorption of one's own post-war predicament (especially in the immediate aftermath of the war) awarded only a very low priority to remembering the tragedies of others, of those who were more peripheral to one's own respective national existence (Dower, 2004: 226; Lagrou, 2004: 411).

Western European countries that had experienced the trauma of defeat and occupation in World War II (i.e. France, Belgium, the Netherlands) felt a deep need for patriotic memories and renewed national epics, although this did not leave much space for their immediate post-war commemoration of the destruction of European Jews, as the memory of the genocide was not of particularly constructive value for their respective patriotic memories. ${ }^{9}$ Similarly, the memory of the Western failure to keep Eastern European states from falling behind the Iron Curtain had a remarkably low benefit for Western Europeans' image of their own national martyrdom (cf. Lagrou, 2004: 41 1; Lebow, 2006: 29-32). Nonetheless, since the international celebrations of the 50th anniversary of the end of World War II in 1995, there have been continuous attempts to transform the fragmented West European memories of Nazi aggression and occupation into a more 'shared and selfcritical memory of an era of European human-rights abuses that unites former victims, perpetrators, and bystanders, and lends legitimacy to the European Union' (Kansteiner, 2006: 120-30). This construction has further enabled the retroactive inclusion of Germany in the renewed European remembrance of World War II, with Schröder's declaration of the Allied campaign as a victory for Europe as well as for Germany (2005; cf. Zehfuss, 2007: 203-8; Olick, 1999). 


\section{The Politics of World War II Commemoration in Moscow}

The 'interpretation war' over the meaning of the end of World War II for different European countries reached its peak during the debates around the commemoration of the 60th anniversary of the end of the war in Moscow. The questions of what precisely to commemorate, whether or not Moscow was the appropriate place for this commemoration in the first place, and when the end of World War II should be commemorated were all brought to the surface in the battles between competing historical narratives of the Baltic states and Poland, Russia and the former Western allies. The clash of narratives about the meaning and ramifications of World War II led to mutual insinuations about attempts to rewrite history between Russia and the Baltic states, in particular, as they struggled to win Western sympathy and support for their contradictory stories of their immediate past. The commemoration controversy of 2005 epitomized the complex interaction between three different levels of Polish and Baltic memory politics over the implications of World War II, namely, the domestic, bilateral and European planes of debating the filtering of historical facts through particular cultural lenses (see Onken, 2007).

For Russians, 9 May 1945 is the date of the Soviet Union's final victory over Nazi Germany, signifying the end of a war in which they suffered massive losses. Indeed, it was on 9 May 1945 that the war ended for the Soviet Union as the defenders of Berlin finally surrendered. ${ }^{10}$ It is therefore a 'sacred day' for Russia; 'one of the most memorable and important dates' in the history of the Russian people, the 'closest, sincerest and most truly national holiday' that marks 'a victory of civilisation over barbarism in the form of fascism' (see Putin, 2005b, 2005c). The commemorative ceremonies of Victory Day, as it is called in Russia, are thus one of the main reservoirs of the modern Russian collective memory, sustaining the progress-glorifying messianism that communist Russia tried to embody in the course of the 20th century and perhaps even retaining an age-old Russian general messianism that pre-dates communism. Altogether, the victory of World War II is the only victory of the Russian people that is celebrated throughout the world today; indeed, the last event in which modern Russia can proudly claim something universal in its specificity (cf. Minaudier, 2007). As such, 9 May also harbours considerable potential for Russia's self-affirmation as a 'normal' European country, not as permanently erring from the 'normal' course of development associated with the West (see Wydra, 2007: 238). The declaration of 8 and 9 May as Days of Remembrance and Reconciliation by the United Nations in 2004 is therefore proudly presented as a special success for Russia and the other Commonwealth of Independent States' diplomacy. 
For the Western Allies, World War II ended in Europe on 8 May 1945 when the capitulation act of the German army was signed in Reims in France, ${ }^{11}$ and 9 May has a different meaning in the EU: it is celebrated as Europe Day in order to commemorate Robert Schuman's call in 1950 for recognition of the fact that European cooperation sprang from the need to reconcile different European nations with each other. For the Eastern European states, there are further 'multiple endings of World War II'. The restoration of their independence in the early 1990s, the withdrawal of the remnants of the Soviet army from the Baltic states, their inclusion in the EU and NATO, and, most recently, even the hosting of a NATO summit in Riga in November 2006 have all been applauded as a sign of the ultimate end of World War II in the region. The date 9 May has thus no single meaning that is univocally shared throughout Europe: the liberation from the Nazi scourge for Western Europe and the Soviet Union was only half a liberation for Eastern Europeans as the day, when according to Putin 'great justice was done' (2005b), marked the beginning of an era of new injustice for them by their subjection to Soviet rule.

The commemoration of the 60th anniversary of the end of World War II as a major celebration of the victory and reconciliation in Moscow on 9 May 2005 was therefore bound to be controversial. The Russian president Vladimir Putin had invited over 50 world leaders to attend a military parade on Red Square in order to celebrate 'the victory of good over evil and of freedom over tyranny', the 'peace and triumph of justice' (Putin, 2005b, 2005 c); indeed, 'the Victory of Life over Death' (Lavrov, 2005). The Victory Day commemorations in Moscow were thus meant to remind the international community of the decisive role Russia played in winning World War II as well as to celebrate the master narrative of Russian identity against the backdrop of the war according to which Russia was the heroic liberator of Europe from the Nazi curse. The aim of the celebrations was therefore not merely 'upholding the historical truth about the war', but also 'fixing firmly in public consciousness a correct understanding of its lessons from the viewpoint of contemporary world development' (Lavrov, 2005).

The very attempt to fix 'a correct understanding of the past', noticeably devoid of self-criticism, touched the crux of the problem for the Baltic states and Poland which do not share the Russian interpretation of the outcomes of World War II. Referring to their unwillingness to celebrate the glory of the Soviet victory on the day that symbolizes the beginning of a new era of oppression for the Baltic states, and emphasizing the need to distinguish between commemorating the victims of the war from the attempts to eulogize the ideological inheritance of the Soviet totalitarian regime, the presidents of Lithuania and Estonia - Valdas Adamkus and Arnold Rüütel therefore declined Putin's invitation, after much debate in their respective 
countries. The presidents of Latvia and Poland, however, decided to attend the commemorative events in Moscow for the very same reason: to draw international attention to the complexity of the outcomes of World War II in Poland and the Baltic states by showing how the Allied victory over Nazi Germany was 'only a partial victory' as the Western democracies 'accepted without protest the renewed subjugation of over a dozen countries in Central and Eastern Europe by the totalitarian communism of the Soviet empire and its satellites' (Vìke-Freiberga, 2005d). Moreover, while the official Russian narrative tends to equate the beginning of World War II for Russia with the beginning of their Great Patriotic War when the Nazis invaded the Soviet Union (i.e. 22 June 1941), the Baltic states and Poland emphasize that the seeds of the conflagration, not to mention the invasion of Poland and the Baltics, were sown already with the Nazi-Soviet pact of 1939. Arguably then, had Nazi Germany and the Soviet Union not agreed to secretly divide the territories of Eastern Europe among themselves, World War II might not have occurred. Since it is both Hitler and Stalin who 'bear the brunt of the blame' for the war, these 'two totalitarian tyrants' should be mentioned by name, as well as commemorating the crimes against humanity of both; lest the responsibility they bear for beginning that war be forgotten (Vikse-Freiberga, 2005d).

Hence, the Baltic states and Poland on the one side and Russia on the other have clashingly contradictory narratives of World War II. What was glory for Russia, was humiliation for the Baltic states and Poland; what Russia as the legal successor of the Soviet Union celebrates as its victory in World War II, the Baltic Three and Poland execrate as a loss of independence, identity and thus their meaningful existence. The collective memories of World War II in Russia and Poland and the Baltic Three have thus proved to be incommensurable to date, and the end of the war is an event still seen in completely different lights.

Paraphrasing Tzvetan Todorov, we could thus say that the Russian commemoration of the 60th anniversary of the end of World War II constituted an attempt to adapt the past to the needs of the present by claiming credit for the decisive significance of the Soviet army in the course of World War II and thus emphasizing the role of Russia in the constitution of modern Europe. The focus of the respective memory-political moves of the Baltics and Poland has, however, rather been on the rememoration of the end of the war in order to try to explain the complex outcomes of it for different European nations; or, indeed, to grasp the 'truth of the past' (2003: 133). After all, for the Western democracies which had never actually fought the USSR, the 'evilness' of Stalin could not quite compete with that of Hitler in their popular consciousness, thus leaving the Baltic states and Poland with 
quite a bit of 'revelatory work' to do on the 'Western front' (cf. Davies, 2006: $242-3) .^{12}$

The Latvian president Vaira Viķe-Freiberga, in particular, launched a vigorous initiative to introduce the dubious outcome of World War II in the Baltic states to the international community, receiving thus an acknowledgement as the Lady der Vergangenheitsbewältigung in the German press. In order to avoid the reefs of belittling the significance of the victory over Nazism while condemning the crimes of Soviet totalitarianism, VikeseFreiberga chose to draw a clear distinction between the meanings of 8 May and 9 May, thus distancing the Latvian, or Baltic, understanding of the end of World War II from the Russian interpretation and emphasizing the significance of 9 May as Europe Day instead. Viķe-Freiberga's statements regarding the commemoration of the 60th anniversary of the end of World War II in Moscow in 2005 were explicitly intent on revealing the 'other side' of the Soviet participation in the war, as well as calling for Western support to encourage Russia to express its regret over the post-war subjugation of Eastern Europe as a direct ramification of the Molotov-Ribbentrop Pact (MRP).

Viķe-Freiberga thus made a conscious attempt to enlarge the semiotic field of connotations of World War II in the Western public imaginary by emphasizing that while the Allied victory over Nazi Germany was indeed a 'victory of democratic values over totalitarianism and tyranny' (2005c), it was nevertheless a victory that failed to bring freedom to 'the other half of Europe' (2006). Therefore, as 'no wound can truly heal if it is festering beneath the surface', Russia should follow the example of Germany who has repeatedly apologized for its Nazi past, 'by expressing its genuine regret for the crimes of the Soviet regime', in particular for its occupation of the Baltic states for 50 years, or 'it will continue to be haunted by the ghosts of its past, and its relations with its immediate neighbours will remain uneasy at best' (2005c, 2005d, 2006). Similar calls were made by her Estonian, Lithuanian and Polish counterparts.

Russia's reaction has, however, been all but apologetic: the official Russian line denies the equivalence of Stalin with Hitler. Russia's critical selfreflection against the backdrop of World War II has been hamstrung by the fact that for Russians, perhaps more than for any other nation, the crimes and acts of heroism in the war are embedded in the very same historical moment. Russia's difficulties in critically engaging with its communist legacy are all the more problematic because the Soviet era marked a period of unprecedented international power for the country, and a critical assessment of this period is therefore seen as a potential challenge to its position in the international arena at the time. Against that backdrop, Stalin's role tends to be viewed in Russia first and foremost as a saviour from the 'Nazi curse' and 
not repudiated for his regime's mass repressions, either in Russia itself or in the former Soviet Union as a whole.

Putin demonstrates the cunning pick-and-choose approach to history that Russia so frequently entertains while engaging with its communist legacy: when useful to today's Russia, the country's direct legal succession from the Soviet Union is emphasized; when harmful, however, such as in the case of admitting to the criminal acts of the previous regime, Russia's direct succession from the USSR is refuted. ${ }^{13}$ After all, admitting responsibility for an act through an apology commits one to some form of reparation. Putin therefore argues that a Russian apology to the Baltic states for the repressions of the Soviet regime 'would be fairly logical only if these peoples had been at any time citizens of the Russian Federation' - which they, of course, never were (2005a). Nevertheless, Putin's speeches do not actually contain traces of the widely accepted idea in Russia that the annexation of the Baltic states was legitimate since it was allegedly based on legitimate referenda. Putin has even expressed regret for the Baltic states' historical usage as a 'token' in world politics, describing the MRP as a 'tragedy'. Yet, any questioning of Eastern Europe's 'liberation' by the Soviet Union has met his immediate rebuttal. In order to disperse Russian responsibility for the fate of the Baltics after World War II, he further argues that the West could not lay any blame on the USSR for annexing the Baltic states in particular since 'these were the realities of those times, just as colonial policies were the realities of quite a large number of European countries'. Hence, just as the Allies 'divided up the spheres of influence', the Soviet Union simply 'established its policies with its close neighbours and its allies ... in its own image' (Viḳe-Freiberga, 2005a). Putin's and his regime's resistance to use the notion of occupation for describing the Soviet takeover of the Baltic states in the course of World War II exemplifies how using a word cannot be reduced to the mere application of a label: insofar as invoking a term calls up a range of further acts that should follow, the use of a particular word(ing) is essentially an act (see Fierke, 2002).

Russia's selective remembrance of World War II exemplifies vividly how present concerns determine which past is remembered and how. For Russia, that is resolutely seeking to re-establish its international position amongst the 'great powers' today, the role of the MRP in sowing the seeds of World War II as well as leading to the ultimate subjugation of Eastern Europe under the Soviet yoke is largely irrelevant for it conflicts with Russia's 'usable remembrance' of the war. Focusing instead on the Soviet Union's hugely costly victory over Nazism enables Putin's regime to position Russia firmly among the 'normal' European countries. The attempts to institutionally monopolize and fix certain meanings of the past further demonstrate that the 'interpretation wars' over past events are substantially struggles over 
power - as the control over the narratives of the past facilitates control over the construction of further narratives for an imagined future. Hence, the Russian political elites' maintenance of the narrative of the Baltic states' voluntary joining with the Soviet Union consequently allows it to shed its responsibility for the communist crimes in the region as well as to demand full citizenship and political rights for the Russians living there since the Soviet period. The culpability of the official Russian stance vis-à-vis the record of World War II does not then really lie in selecting those parts of the past that it wishes to preserve (which is, after all, human, all too human), but in granting itself a 'natural' right to decide what would be available to others (i.e. the victims of the Soviet regime). In a manner characteristic of a great power, the Soviet Union used a method of organized forgetting in the Baltic states and Poland over the communist period in order to try to deprive them of their national consciousnesses. In a similar fashion, as we will see below, when Russia encounters interpretations of history that diverge from its own, the propaganda war for getting across its own version of the past events usually follows.

Nevertheless, the vigorous memory-political offensive by Viḳe-Freiberga found considerable support and understanding among the Baltics' and Poland's Euro-Atlantic partners. In his letter to the Latvian president, US president George W. Bush, for example, reminded her that while 'in Western Europe, the end of WWII meant liberation', in Central and Eastern Europe, 'the war also marked the Soviet occupation and annexation of Estonia, Latvia and Lithuania and the imposition of communism' (2005a). Bush's 'pit-stop' in Riga a few days before his attendance at the Moscow commemorations to mark the anniversary of World War II was also read as a signal of sympathy to the Baltic states as well as an attempt to balance the Russian self-glorifying emphasis on Nazi Germany's defeat with a condemnation of the subsequent Soviet subjugation of Eastern Europe. Bush even acknowledged that the US bore some blame for the 'division of Europe into armed camps', vowing never again to trade freedom for stability, thus arguably also providing a model for Putin to renounce the Soviet occupation of the Baltic states (2005b). The US Congress, in turn, passed a resolution on 22 July 2005 in support of the Baltic case, arguing that 'the truth is a powerful weapon for healing, forgiving and reconciliation, but its absence breeds distrust, fear, and hostility' (Congress of the United States of America, 2005), thus seeking an acknowledgement and condemnation by the Russian Federation of the Soviet Union's occupation of the Baltic states.

The official declaration of the European Commission issued on Europe Day was much more lukewarm in its tone, promising euphemistically to remember also 'the many millions for whom the end of the Second World War was not the end of dictatorship, and for whom true freedom was only 
to come with the fall of the Berlin Wall' (2005). The respective resolution of the European Parliament (EP), entitled 'The Future of Europe Sixty Years after the Second World War', pointed more directly to the 'renewed tyranny inflicted by the Stalinist Soviet Union' on East European nations after the end of World War II, and acknowledged the 'magnitude of the suffering, injustice and long-term social, political and economic degradation endured by the captive nations located on the eastern side of what was to become the Iron Curtain' (2005). The resolution explicitly highlighted the significance of keeping the memories of the past alive, 'because there cannot be reconciliation without truth and remembrance'. Further, it confirmed the EP's united stand against 'all totalitarian rule of whatever ideological persuasion'; welcomed 'the fact that the Central and Eastern European states and peoples can now also enjoy freedom and the right to determine their destiny after so many decades under Soviet domination or occupation or other communist dictatorships', and called on all countries to open their archives pertaining to World War II (European Parliament, 2005).

Yet again, however, very different treatments of Europe's immediate past clashed during the preparations that preceded the adoption of the final version of the document. There were MEPs who regarded the resolution as 'a repellent exercise in revisionism and historical distortion', as a 'dreadful falsification of history' aiming to 'wipe out the key contribution made by the Soviet Union and its people's glorious struggle to destroy the brutal killing machine of the Nazi Fascist armies and regimes'; moreover, as an attempt to 'silence and defame the glorious and heroic role played by the communists in the anti-fascist struggle' (Guerreiro, 2005). Refuting thus the attempts to compare the crimes of communism with those of Nazism, these voices argued vigorously against 'indistinctly muddling 8 May 1945 with the crimes of Stalinism' (Catania, 2005; cf. Wurtz, 2005). ${ }^{14}$

The Baltic and Polish endeavours to seek international condemnation of the crimes of the communist regimes in Eastern Europe bore more fruit with the adoption of the relevant resolution by the Parliamentary Assembly of the Council of Europe (PACE) on 25 January 2006, which explicitly condemned the crimes committed by totalitarian communist regimes. This resolution acknowledges that the fall of totalitarian communist regimes in Central and Eastern Europe has not been followed in all cases by an international investigation of the crimes committed by them, nor have the perpetrators of these crimes been brought to trial by the international community in a similar fashion to the way in which Nazi crimes were once addressed in Nuremberg. Consequently, the resolution points to the fact that public awareness of crimes committed by totalitarian communist regimes is 'very poor'. Acknowledging that the awareness of history is one of the preconditions for avoiding similar crimes in the future, the resolution 
regards the moral assessment and condemnation of the communist crimes as playing an important role in the education of the younger generations and thus preventing history from repeating itself. Condemning the massive human rights violations committed by the totalitarian communist regimes, the resolution also expresses sympathy to the victims of these crimes, thus calling for extending moral restitution for their sufferings. ${ }^{15}$ Furthermore, the resolution calls on all communist or post-communist parties in its member states to reassess the history of communism and their own past in case they had not done it already, to 'clearly distance themselves from the crimes committed by totalitarian communist regimes and condemn them without any ambiguity' (PACE, 2006; cf. OSCE PA, 2009).

Yet, PACE's draft recommendation calling on European governments to adopt a similar declaration on the international condemnation of crimes of totalitarian communist regimes, to carry out legal investigations of individuals engaged in such crimes and create the prerequisites for the 'memory work' of the European nations that had suffered under the communist regimes (i.e. open up the archives, build monuments and museums commemorating the victims, revise the textbooks, or introduce national commemoration days) did not receive the necessary two-thirds majority of the votes cast. Notably also, the final text of the resolution did not even mention the Soviet Union, not least as a result of the successive Russian mobilization of the European ultra-leftists and communists to oppose the resolution as such, or at least to disperse, erase and reword several paragraphs of the resolution's initial project. ${ }^{16}$

The debates over the condemnation of the crimes of communism in different European fora as well as the 'crisis of May 2005' brought forward the special case status of Poland and the Baltic states, in particular, in European history and politics while simultaneously making a case against their different treatment in the collective remembering of World War II in Europe. The political controversies around the 60th anniversary of World War II could be regarded as a turning point in European memory politics. The intense public debates and the unprecedented international attention given to the Baltic cause in particular helped to illuminate and clarify the diverging perceptions of the past, thus raising the general awareness about diverse historical legacies of the war and their direct impact on today's politics in different parts of Europe (cf. Onken, 2007: 43-4).

\section{'East is East, and West is West, and Never the Twain Shall Meet?'17}

Yet, it is difficult but to agree with Duncan Bell who predicts that conflict rather than harmony determines the contours of future mnemonic politics of Europe (2006: 16). For the Baltic states and Poland, the subjugation to the 
Soviet rule and the eventual end of the Cold War emerge as the constitutive events of the past 50 years. For Western Europeans, the German-French reconciliation tends to figure as a central landmark in the post-World War II collective historical consciousness.

As the terrain of memory of the 'united Europe' remains as contested as ever, there does not seem to be much space for any great optimism about the early emergence of a common European self-conceptualization. It is questionable whether producing a single and definitive collective 'version of the past' that is commonly shared by the public within a given community is at all possible or even desirable. There is thus also some hope in this scarcity of an all-European mnemonical consensus, for the struggle over memory is nevertheless preferable to the prospect of a politically institutionalized collective memory as an infinitely closed book (à la George Orwell) which would inevitably subordinate some sets of victims and ideals to the overarching narratives of the others.

Calls for a common historical memory for Europe have therefore inevitably revealed certain sore points that have traditionally been put under cover for the sake of the 'united Europe' myth. Apparently, Europe's history has been written as that of the sum of national histories that have been considered to be more important, thus leading to the 'marginalisation or complete exclusion of smaller or "peripheral" states and alternative topics' (see Fulbrook, 1993: 2). There has been a noticeable bias in favour of Western and Southern Europe to the detriment of Northern and Eastern Europe in writing the history of 'Europe'. Moreover, according to Davies, 'automatic priority is given to positive and uplifting aspects of the past, whilst negative or disturbing subjects are systematically avoided', leading him to conclude that Western civilization is a 'power cult' indeed (2006: 49-50). Rebelling against the Western European rendering of their own mnemonic culture as obligatory for all others, the Polish and Baltic reappropriation of their pasts and their attempts to bring these 'minority pasts' into the common European historical consciousness challenge the long-term tendency of the old Western core of the EU to act as a model for the whole of Europe. After all, remembering certain events does not only define the content of a collective memory but also the extent of the remembering community (Eder, 2006: 267). Any remembrance is inevitably already marked by forgetting and the complex question of Western co-responsibility for Eastern Europeans' post-war submission under communist rule only made the intentional 'forgetting' of certain aspects of World War II more attractive for them (cf. Zehfuss, 2006, 2007).

What is really needed, then, is a critical history of the politics of 'common European memory' of World War II that would expose the dense ambiguity and complexity of the past as well as show the genealogical 'becoming' of 
certain institutionalized versions of it. As any politically endorsed collective memory is essentially the product of specific power relations, it is important to explore how and why it has emerged in a particular form as well as the processes of inclusion and exclusion that have underpinned it. Who has been, at the end of the day, the 'we' doing the remembering of World War II in the EU? Poland's and the Baltics' desire to be heard in Europe hence also implies their commitment to making history of this mnemonical community (cf. de Certeau, 1997: 32).

Yet, the project of a united Europe will probably require the readjustment of historical narratives from all sides to allow for a more heterocentric European mnemonical vision to emerge. It is also fair to assume that just as European national identities are influenced, but not replaced, by a 'common European identity', national memories are likewise transfigured by a transnational European collective memory under the impact of Europeanization, yet not substituted for it (cf. Spohn, 2005: 3-4). Furthermore, the accumulation of different 'subaltern European pasts' does not automatically produce new knowledge and understandings of European history, as besides factual authenticity it arguably matters a great deal through what structural access and under what socio-historical conditions people come to an awareness of these pasts (see Yoneyama, 2004: 456).

At the end of the day, it would be a categorical mistake to predict the imminent emergence of the common European historical vision in the first place. The question remains whether it would really be viable to produce a better representational account of Europe's problematic history in a singular pan-European narrative which would not merely incite a further proliferation of different histories. As the attempts to invent a shared past only tend to provoke more or less violent expressions of difference, it seems advisable for the EU not to focus on 'settling its memory problem', but to try to allow space for competing narratives, and find peaceful, if agonizing, ways to express and provoke different versions of the past instead. The conflicting claims made by various national and subnational representatives of 'old' and 'new' Europeans should be given consideration, highlighting how and why certain historical events have acquired particular significance for different communities in the East and West of Europe.

\section{Notes}

1. The subtlety of subnational mnemonical cleavages that was most recently exposed in Estonia during the 'Bronze Soldier' controversy in the spring of 2007 remains out of the scope of this article. On this, see further Mälksoo (2009). For a thorough study of remembrance practices that might challenge state power and encourage radical political change, see Edkins (2003). 
2. For a perceptive discussion about the unlikelihood of a fully harmonized European memory on World War II, see Bell (2006). Yet, he argues that to entirely rule out the possibility of future transformation would also be unwise, which only makes the study of the transnational dissemination of memory across various contexts more important.

3. Cf. de Certeau (1986).

4. With the remarkable exception of Courtois et al. (1999). Cf. Solzhenitsyn (1974) and Applebaum (2003).

5. This has not been quite the case with the academic and political attention dedicated to the crimes of communism in the United States (US) where during the Cold War considerable resources were put into the research and publicity of these issues. Yet, much of the early US research on the topic also had clearly propagandistic aims. Characteristically against this backdrop, the monument to the victims of communism has also been raised in the US, not in Europe.

6. Although the emergence of 'Eurocommunism' in the mid-1970s, as a result of Western European left-wing intelligentsia's gradual awakening to the Stalinist crimes and the adjacent heated debates, nevertheless cleared some of the air in that regard.

7. Cf. Meri (2000). Calls to establish an international museum in the US dedicated to the commemoration and research of the crimes of communism by the example of the Holocaust Museum in Washington, DC, constitute a paradigmatic quest in that context. Cf. Luik (2008).

8. For an elaboration on this theme, see Mälksoo (2006: 283-6).

9. In a curious resemblance, Eastern European nations' post-Cold War 'mnemopolitical unfreezing' has been as slow and recalcitrant towards recognizing the 'other in oneself' - their own participation in massive abuses of human rights in the course of World War II not merely as victims but also as perpetrators. Consider, for instance, the Polish collaboration in the 1941 Jedwabne massacre of hundreds of Jews, or general sensitivity towards acknowledging the sufferings of the German refugees and expellees from Eastern Europe.

10. Also, the Red Army fought in Prague till 9 May 1945. Technically, however, World War II did not end for the Soviet Union before the surrender of Japan in late August since the USSR had joined the Allies' war against Japan on 8 August 1945 , just about a week before the latter's ultimate capitulation.

11. However, while the end of the war was already celebrated in Europe, the fighting in Asia carried on.

12. Again, Nazism's status as 'absolute evil' has been more nuanced in the postWorld War II US where Nazi Germany and Soviet Russia became merged under the catchphrase of 'Red Fascism' in the American image of totalitarianism.

13. Accordingly, Russia has denied access to documents regarding the assassination of Polish reserve officers in the Katyn Forest in the spring of 1940 by the Soviet security police.

14. It was only on 30 March 2009 when the EP unequivocally condemned the crimes of the totalitarian communist regimes. 
15. According to Courtois et al. (1999), approximately 20 million people fell victim to Soviet mass crimes from the 1920s to the 1950s; the Soviet occupation and de facto control in Central and Eastern Europe, in turn, resulted in approximately one million victims.

16. The practice-oriented initiative of members of the EP from former communist countries (spearheaded by Jószef Szájer from Hungary and Vytautas Landsbergis from Lithuania) to urge the EU ban of the communist symbols (i.e. sickle and hammer) alongside the swastika, proved ultimately unsuccessful as well.

17. The subtitle is a quotation from Rudyard Kipling's The Ballad of East and West (1895).

\section{References}

Adorno, Theodor (1986) 'What Does Coming to Terms with the Past Mean?', in Geoffrey Hartman (ed.) Bitburg in Moral and Political Perspective, pp. 114-29. Bloomington, IN: Indiana University Press.

Applebaum, Anne (2003) Gulag: A History. New York: Doubleday.

Assmann, Jan (1992) Das culturelle Gedächtnis: Schrift, Erinnerung und politische Identität in frühen Hochkulturen. Munich: Beck.

Bell, Duncan (2006) 'Introduction: Memory, Trauma and World Politics', in Duncan Bell (ed.) Memory, Trauma and World Politics: Reflections on the Relationship Between Past and Present, pp. 1-29. Basingstoke: Palgrave Macmillan.

Bush, George W. (2005a) 'Letter of the President of the United States to the Latvian President Vaira Vỉke-Freiberga'. 3 May.

Bush, George W. (2005b) 'Remarks by the President of the United States at the Small Guild Hall, Riga', 7 May.

Catania, Giusto (2005) 'Speech in Plenary of the European Parliament on the Future of Europe Sixty Years after the Second World War', P6_CRE(2005)05-11, 11 May.

Churchill, Winston (1946) 'Speech to the Academic Youth in Zürich, Switzerland', 19 September.

Congress of the United States of America (2005) Concurrent Resolution 128 (H.CON. RES. 128), 22 July.

Connolly, William E. (1999) 'Suffering, Justice, and the Politics of Becoming', in David Campbell and Michael J. Shapiro (eds) Moral Spaces: Rethinking Ethics and World Politics, pp. 125-53. Minneapolis, MN and London: University of Minnesota Press.

Courtois, Stéphane (1999) 'Introduction: The Crimes of Communism', in Stéphane Courtois et al. (eds) The Black Book of Communism: Crimes, Terror, Repression, trans. Jonathan Murphy and Mark Kramer, pp. 1-31. Cambridge, MA: Harvard University Press.

Courtois, Stéphane, Nicolas Werth, Jean-Louis Panné, Andrzej Packowski, Karel Bartošek and Jean-Louis Margolin (eds) (1999) The Black Book of Communism: Crimes, Terror, Repression, trans. Jonathan Murphy and Mark Kramer. Cambridge, MA: Harvard University Press. 
Davies, Norman (2006) Europe East and West. London: Jonathan Cape.

Davies, Norman (2007) Europe at War 1939-1945: No Simple Victory. London: Pan Books.

Deák, István, Jan T. Gross and Tony Judt (eds) (2000) The Politics of Retribution in Europe: World War II and its Aftermath. Princeton, NJ: Princeton University Press.

de Certeau, Michel (1986) Heterologies: Discourse on the Other, trans. Brian Massumi. Manchester: Manchester University Press.

de Certeau, Michel (1997) The Capture of Speech and Other Political Writings, trans. Tom Conley. Minneapolis, MN and London: University of Minnesota Press.

Donskis, Leonidas (1999) 'Between Identity and Freedom: Mapping Nationalism in Twentieth-Century Lithuania', East European Politics and Societies 13(3): 474-500.

Dower, John (2004) 'Race, Language, and War in Two Cultures: World War II in Asia', in Gordon Martel (ed.) The World War Two Reader, pp. 226-49. New York and London: Routledge.

Eder, Klaus (2006) 'Europe's Borders: The Narrative Construction of the Boundaries of Europe', European Journal of Social Theory 9(2): 255-71.

Edkins, Jenny (2003) Trauma and the Memory of Politics. Cambridge: Cambridge University Press.

European Commission (2005) Europe Day Commission Declaration, 9 May, no. $49 / 05$.

European Parliament (2005) 'The Future of Europe Sixty Years after the Second World War', Resolution on the Sixtieth Anniversary of the End of the Second World War in Europe on 8 May 1945, P6_TA(2005)0180, 12 May.

Fierke, Karin M. (2002) 'Links Across the Abyss: Language and Logic in International Relations', International Studies Quarterly 46: 331-54.

Fulbrook, Mary (1993) 'Introduction: States, Nations, and the Development of Europe', in Mary Fulbrook (ed.) National Histories and European History, pp. 1-17. London: UCL Press.

Guerreiro, Pedro (2005) 'Speech in Plenary of the European Parliament on the future of Europe Sixty Years after the Second World War', P6_CRE(2005)05-11, 11 May.

Ilves, Toomas Hendrik (2003) 'Taassünni ajalooline valu' [The Historic Pain of the Rebirth], Eesti Päevaleht 17 July.

Irwin-Zarecka, Iwona (1994) Frames of Remembrance: The Dynamics of Collective Memory. New Brunswick, NJ: Transaction.

Jarausch, Konrad H. and Thomas Lindenberger (2007) 'Contours of a Critical History of Contemporary Europe: A Transnational Agenda', in Konrad H. Jarausch and Thomas Lindenberger (eds) Conflicted Memories: Europeanizing Contemporary Histories, pp. 1-20. New York and Oxford: Berghahn Books.

Judt, Tony (1992) 'The Past is Another Country: Myth and Memory in Postwar Europe', Dedalus 4: 83-118.

Judt, Tony (1994) 'Nineteen Eighty-Nine: The End of Which European Era?', Dedalus 3: 1-19. 
Judt, Tony (2005) Postwar: A History of Europe since 1945. London: William Heinemann.

Kalniete, Sandra (2003) 'Address by the Latvian Minister of Foreign Affairs at the International Donors' Conference on Reconstruction in Iraq', Madrid, 24 October.

Kansteiner, Wulf (2006) 'Losing the War, Winning the Memory Battle: The Legacy of Nazism, World War II, and the Holocaust in the Federal Republic of Germany', in Richard Ned Lebow, Wulf Kansteiner and Claudio Fogu (eds) The Politics of Memory in Postwar Europe, pp. 102-46. Durham, NC and London: Duke University Press.

Kelam, Tunne (2008) 'Applying Equality and Common Values to the Perception of the European history: Suggestions on Assessment of Totalitarian Communism', Speech by the Estonian MEP at the European Parliament conference 'United Europe, United History', 22 January.

Kipling, Rudyard (1895) The Ballad of East and West. Available at http://www. bartleby.com/246/1129.html (accessed 3 December 2007).

Kristovskis, Ģirts Valdis (2008) 'A Level Playing Field: A Few Legal Aspects', Speech by the Latvian MEP at the European Parliament conference 'United Europe, United History', 22 January.

Kwaśniewski, Aleksander (2002) 'Letter of the President of Poland to Participants of Academic Conference on Operation "Vistula", Warsaw, 18 April.

Lagrou, Pieter (2004) 'Victims of Genocide and National Memory: Belgium, France and the Netherlands 1945-65', in Gordon Martel (ed.) The World War Two Reader, pp. 389-421. New York and London: Routledge.

Lavrov, Sergey (2005) 'Lessons of the Great Victory', Diplomat 5 May.

Lebow, Richard Ned (2003) The Tragic Vision of Politics: Ethics, Interests and Orders. Cambridge: Cambridge University Press.

Lebow, Richard Ned (2006) 'The Memory of Politics in Postwar Europe', in Richard Ned Lebow, Wulf Kansteiner and Claudio Fogu (eds) The Politics of Memory in Postwar Europe, pp. 1-39. Durham, NC and London: Duke University Press.

Luik, Jüri (2008) 'Meie kohustus: ettepanek asutada komisjon Euroopas sooritatud kommunismi kuritegude uurimiseks' [Our Obligation: A Proposal to Establish a Commission for the Investigation of Communist Crimes in Europe], Diplomaatia 2(54): 10-11.

Lukas, Richard C. (1997) Forgotten Holocaust: The Poles under German Occupation 1939-1944. New York: Hippocrene.

McLennan, Gregor (2003) 'Sociology: Eurocentrism and Postcolonial Theory', European Journal of Social Theory 6(1): 69-86.

Malia, Martin (1999) 'Foreword: The Uses of Atrocity', in S. Courtois et al. (eds) The Black Book of Communism: Crimes, Terror, Repression, trans. Jonathan Murphy and Mark Kramer, pp. ix-xx. Cambridge, MA: Harvard University Press.

Mälksoo, Maria (2006) 'From Existential Politics Towards Normal Politics? The Baltic States in the Enlarged Europe', Security Dialogue 37(3): 275-97.

Mälksoo, Maria (2009) 'Liminality and Contested Europeanness: Conflicting Memory Politics in the Baltic Space', in Eiki Berg and Piret Ehin (eds) Identity 
and Foreign Policy: Baltic-Russian Relations and European Integration, pp. 65-83. Aldershot: Ashgate.

Meri, Lennart (1993) 'Me tunneme muretuse koletut hinda' [We Know the Awful Price of Insouciance], Speech at the Reception of the President of the Republic of Poland, 6 May.

Meri, Lennart (1999a) 'Speech by the President of the Republic of Estonia on the Seminar on the Communist Crimes', Stockholm, 13 April.

Meri, Lennart (1999b) 'Speech by the President of the Republic of Estonia on the Baltic Development Forum', Copenhagen, 17 May.

Meri, Lennart (2000) 'Speech by the President of the Republic at the Presentation of the Estonian Translation of The Black Book of Communism', Tallinn Town Hall, 12 December.

Miłosz, Czesław (1953) The Captive Mind, trans. Jane Zielonko. London: Secker and Warburg.

Minaudier, Jean-Pierre (2007) 'Ühe kuupäeva ajalooline ja poliitiline tagapõhi: 8. ja 9. mai Prantsusmaal, Balti riikides ja Venemaal' [The Historical and Political Background of a Date: 8 and 9 May in France, the Baltic States and Russia], Vikerkaar 1-2: 133-41.

Mostov, Julie (1998) 'The Use and Abuse of History in Eastern Europe: A Challenge for the 90s', Constellations 4(3): 376-86.

Müller, Jan-Werner (2002) 'Introduction: The Power of Memory, the Memory of Power and the Power over Memory', in Jan-Werner Müller (ed.) Memory and Power in Post-War Europe: Studies in the Presence of the Past, pp. 1-35. Cambridge: Cambridge University Press.

Nora, Pierre (ed.) (1995) Realms of Memory: Rethinking the French Past. Vol I: Conflicts and Divisions, trans. Arthur Goldhammer. New York: Columbia University Press.

Norton, Anne (1993) 'Ruling Memory', Political Theory 21(3): 453-63.

Olick, Jeffrey K. (1999) 'Genre Memories and Memory Genres: A Dialogical Analysis of May 8, 1945 Commemorations in the Federal Republic of Germany', American Sociological Review 64: 381-402.

Onken, Eva-Clarita (2007) 'The Baltic States and Moscow's 9 May Commemoration: Analysing Memory Politics in Europe', Europe-Asia Studies 59(1): 23-46.

OSCE PA (Organization for Security and Co-operation in Europe Parliamentary Assembly) (2009) 'Resolution on Divided Europe Reunited: Promoting Human Rights and Civil Liberties in the OSCE Region in the 21st Century', Vilnius, 3 July.

Pabriks, Artis (2005) 'Address of the Minister of Foreign Affairs of the Republic of Latvia to the Conference "Coming to Terms with History: Building Mutual Confidence and Cooperation in the Baltic Sea Region"', Copenhagen, 28 April.

PACE (Parliamentary Assembly of the Council of Europe) (2006) 'Need for International Condemnation of Crimes of Totalitarian Communist Regimes', Resolution 1481, 25 January.

Putin, Vladimir (2005a) Interview by the President of Russia with German television channels ARD and ZDF, 5 May. 
Putin, Vladimir (2005b) 'Speech by the President of Russia at a Formal Reception Dedicated to the 60th Anniversary of Victory', The State Kremlin Palace, Moscow, 9 May.

Putin, Vladimir (2005c) 'Speech by the President of Russia at the Military Parade in Honour of the 60th Anniversary of Victory in the Great Patriotic War', Red Square, Moscow, 9 May.

Rousso, Henry (1991) The Vichy Syndrome: History and Memory in France since 1944, trans. Arthur Goldhammer. Cambridge, MA: Harvard University Press.

Roszkowski, Wojciech, Gyorgy Schöpflin, Tunne-Väldo Kelam, Ģirts Valdis Kristovskis and Vytautas Landsbergis (2008) 'United Europe - United History: A Mission to Consolidate a Common Memory', Declaration by the Polish, Latvian, Lithuanian and Estonian MEPs at the European Parliament conference 'United Europe, United History', 22 January.

Said, Edward W. (1994) Culture and Imperialism. New York: Vintage Books.

Schröder, Gerhard (2005) 'Wir stehen erst am Ende einer langen Nachkriegszeit', Süddeutsche Zeitung, 7 May.

Solzhenitsyn, Aleksandr (1974) The Gulag Archipelago, 1918-1956: An Experiment in Literary Investigation, I-II, trans. Thomas P. Whitney. London: Collins/Harvill Press.

Spohn, Willfried (2005) 'National Identities and Collective Memory in an Enlarged Europe', in Klaus Eder and Willfried Spohn (eds) Collective Memory and European Identity: The Effects of Integration and Enlargement, pp. 1-14. Aldershot: Ashgate.

Szakolczai, Arpád (2000) Reflexive Historical Sociology. London and New York: Routledge.

Todorov, Tzvetan (2003) Hope and Memory: Reflections on the Twentieth Century, trans. David Bellos. London: Atlantic Books.

Viḳe-Freiberga, Vaira (2004) 'Address by the President of Latvia at the conference Negotiating Futures - States, Societies and the World', Riga, 12 November.

Vìke-Freiberga, Vaira (2005a) 'Declaration by the President of the Republic of Latvia Regarding 9 May 2005', Riga, 12 January.

Viḳe-Freiberga, Vaira (2005b) 'Statement of the President of Latvia Prior to the Visit of the President of the United States', Riga, 6 May.

Vị̄e-Freiberga, Vaira (2005c) 'Rights and Remembrance', The Washington Post 7 May.

Vīkse-Freiberga, Vaira (2005d) 'Address by the President of Latvia at the Third Summit of Heads of State and Government of the Council of Europe', Warsaw, 16 May.

Viḳe-Freiberga, Vaira (2006) 'Address by the President of Latvia at the Joint Session of the United States Congress', Washington, DC, 7 June.

Wolff, Larry (1994) Inventing Eastern Europe: The Map of Civilisation in the Mind of the Enlightenment. Stanford, CA: Stanford University Press.

Wood, Nancy (1999) Vectors of Memory: Legacies of Trauma in Postwar Europe. New York and Oxford: Berg. 
Wurtz, Francis (2005) 'Speech in Plenary of the European Parliament on the Future of Europe Sixty Years after the Second World War', P6_CRE(2005)05-11, 11 May.

Wydra, Harald (2007) Communism and the Emergence of Democracy. Cambridge: Cambridge University Press.

Yoneyama, Lisa (2004) 'For Transformative Knowledge and Postnationalist Public Spheres: The Smithsonian Enola Gay Controversy', in Gordon Martel (ed.) The World War Two Reader, pp. 449-69. New York and London: Routledge.

Zehfuss, Maja (2006) 'Remembering to Forget/Forgetting to Remember', in Duncan Bell (ed.) Memory, Trauma and World Politics: Reflections on the Relationship between Past and Present, pp. 213-30. Basingstoke: Palgrave Macmillan.

Zehfuss, Maja (2007) Wounds of Memory: The Politics of War in Germany. Cambridge: Cambridge University Press.

MARIA MÄLKSOO is a Researcher at the International Centre for Defence Studies, Tallinn, and a Lecturer at the Institute of Government and Politics at the University of Tartu, Estonia. She gained her Ph.D. in International Studies at the University of Cambridge in 2008 after studies of sociology, political science and international relations at the Universities of Tartu, Montana and Cambridge. Her first monograph The Politics of Becoming European: A Study of Polish and Baltic Post-Cold War Security Imaginaries will appear in Routledge New International Relations Series in 2009. She has previously published in Security Dialogue, Cambridge Review of International Affairs, as well as in several edited books and Estonian academic journals. 